\title{
Leadership scholarship: all bridges have been burned
}

\author{
Jon Aarum Andersen \\ School of Business, Örebro University, Örebro, Sweden
}

\begin{abstract}
The aim of this article is to enhance the understanding of the present state of leadership scholarship by describing similarities between leadership theories and underlining significant differences between them. Based on four criteria, two broad groups of leadership theories are identifiable. These two groups are fundamentally different with respect to the conceptions of both organisations and leadership. While one group of theories concentrates on descriptions and understandings of leadership processes, the other group emphasises causal relationships between leadership and organisational outcomes. A critical result of the divergent emphases is that the theoretical relationships between these two groups of scholarship appear to have ended. Advancements in one area may no longer be beneficial to other areas. This article stresses that it is necessary to come to grips with the consequences of the present fissured state in leadership research.
\end{abstract}

Keywords: leadership theories, assumptions on organisations, definitions of leadership, explanation, understanding, method

\section{INTRODUCTION}

Leadership became an academic field and thus an object of research during the emergence of psychology at the beginning of the twentieth century (Yukl 2013). At this time a large amount of leadership research and a variety of leadership theories were proposed. Now, two broad types of leadership theories have been identified in order to understand the present state of leadership research.

Whenever, in conversation with younger friends, I relate some episode of the time before the first war, I notice from their astonished questions how much that is still obvious reality to me has already become historical and incomprehensible to them. And some secret instinct tells me that they are right. All bridges between our today and our yesterday and yesterday years have been burnt. (Zweig 1942 [1964], p. xix)

In addition to psychology, leadership has also been influenced by sociology, management, history, political science, social anthropology, economics and studies of religion and ethics. No doubt, leadership scholars have produced more and more theories and study objects, issues and approaches. Arguably, leadership has never rested on one academic discipline and may not qualify as a proper academic discipline. It is, however, possible to isolate specific eras when leadership studies have had specific foci (Bass 1990; 2008; Bryman 1996) and perspectives (Yukl 2013). The issue at hand is that leadership theories may have become so fragmented that the relationship between two groups of theories have ended up implying that advancements in one area are no longer beneficial to other areas. 


\section{METHODOLOGY}

In order to navigate through the large amount and diversity of leadership scholarship a number of categories, typologies, taxonomies or approaches have been introduced. In this theoretical work 'the method' pertains to the procedure which is applied in order to address the problem: the consequences of the fragmentation of leadership scholarship due to the large amount of research and theories that has been proposed.

The first step of this procedure concerns categories or groups of leadership theories. Bass $(1990 ; 2008)$ and Yukl (2013) contain the underlying tenets for the categories used. The groups they have proposed are similar to those found in other reference books and textbooks. It is hardly possible to categorise all leadership theories, but it is possible to classify more leadership theories in the same groups or to classify more groups according to more or other features. It is the similarities and consistencies between theories within each group which are the main points in the classifications of Bass (1990; 2008) and Yukl (2013).

The second step in this procedure seeks to unravel differences between the categories. Now, it is the degree of difference between the groups that matters. It is not only a matter of how different the theories and groups of theories are, but it is a matter of the magnitude, strength or depths of these differences.

The third step pertains to the selection of criteria for differentiating between groups of leadership theories. Leadership scholarship has always struggled with definitions and still does. Additionally, a dividing point concerns where leadership emerges and persists. Most leadership studies address leadership in organisations and thus the theoretical assumptions on organisations turn out to be a dividing issue. Leadership scholarship is also basically different in terms of the purpose of the research. Is it to explain or to understand the emergence of, existence of, or consequences of leadership? The issue of methodology is a consequence of the purposes of the research.

Leadership theories are thus categorised according to the following criteria: (1) theoretical assumptions on organisations, (2) definitions of leadership, (3) focus on explanation versus description and understanding, and (4) method and empirical data. These four classification criteria are chosen because they pinpoint significant differences and contrast between a number of theories in order to facilitate an understanding of the present state of leadership scholarship. The use of other criteria and the highlighting of other leadership theories may, however, lead to other conclusions.

Scott (2003) is the main reference regarding category (1), the theoretical assumptions on organisations. Category (2), definitions of leadership, is based on Bass (1990) chapter 1, pp. 11-18, Bass (2008) chapter 1, pp. 6-23, and Yukl (2013) chapter 1, pp. 18-24. The description of the theories which focuses on explanation is similar to Bass (1990) chapter 21, pp. 415-543, Bass (2008) chapters 17-22, pp. 439-648, and Yukl (2013) chapter 3. Category (3), the group of theories on understanding and description, is in line with what is presented in Bass (1990) chapter 20, pp. 391-401, Bass (2008) chapter 23, pp. 651-681, and Yukl (2013) chapter 3 on managerial work. Additionally, Yukl (2013) chapter 13, pp. 328-346, and Richards (2015), chapter 5 address works on symbolic leadership and the construction of leadership. Category (4) concerns method and empirical data and is based on Bass (1990) chapter 37, pp. 864-871, Bass (2008) chapter 36, pp. 1159-1208, and Yukl (2013), chapter 16, pp. 402-408 as well as Antonakis et al. (2004) chapter 3, pp. 54-70.

The fourth step is to reach a theoretical conclusion. It is shown - according to the first criterion - that leadership theories are different in terms of organisational concepts, that is, in what kind of organisations or social, political or religious movements the 
theories apply. The second criterion concerns the definition of leadership while the third pertains to what the purpose of leadership research is: to explain causally relationships between leadership and organisational outcomes or to understand or describe the process of leadership and perceptions of leadership. The differences found between these three criteria are related to differences in methods applied and empirical data collected, which is the fourth criterion. By using this procedure, two main groups of leadership theories emerge.

The two groups contain several theories. Old and current theories appear in both groups. The aim is not to assess specific theories or approaches with regard to their impact, quality, scientific rigour or relevance. For this very reason the groups have been given labels in order as far as possible to avoid potential associations with something good or bad or new or outdated, namely the 'organisational effectiveness theories' and 'process descriptive theories'. 'The organisational effectiveness theories' focus on the explanation of organisational outcomes and address in particular the causal relationship between leadership and organisational effectiveness. What is named 'process description theories' or 'leadership process theories' are theories that help us understand what leadership is or how leadership is understood and perceived or the symbolic aspects of leadership. All that matters is that these two kinds of leadership theories are different. And there is a chasm between them.

\section{ORGANISATIONAL EFFECTIVENESS THEORIES}

\subsection{Theoretical assumptions on organisations}

What is denoted as 'organisational effectiveness theories' addresses leadership in or of formal organisations. In order to study leadership a concept of organisation is necessary. As Scott (2003, p. 11 and 17) has written: 'Most analysts have conceived of organizations as social structures created by individuals to support the collaborative pursuit of specified goals' ... 'A base of divergence among those who study organisation is theoretical perspective employed by the analyst'. One common trait of rationalistic theories of organisation is that organisations are oriented towards the pursuit of relatively specific goals. Goals are specific to the extent that they are explicit, clearly defined and provide unambiguous criteria for selecting between alternative activities. Scholarship on leadership and effectiveness pertains to leadership in formal organisations and is based on the rationalistic theory of organisation which highlights the relationship between the owners and the managers.

Organisations are social phenomena. Moreover, rationalistic theory views the organisation as an instrument, that is, a rationally designed means for the realisation of explicit goals set by a particular group of people (Scott 2003). The study of management and business administration regards organisations as contrived entities that owners have established as vehicles for the achievement of their goals. Goal-attainment is therefore the central issue and the basic definition of effectiveness in management theory.

Shareholders need to delegate control to a few directors and managers to run the company on their behalf (Letza et al. 2004). The main task of formal leaders (that is, managers) is to contribute to the attainment of the goals that the owners have determined. The purpose of the firm is not an issue for managers. It is the reason they hold executive positions. It is crucial to stress that the formulation of purposes, goals, strategies and visions in formal organisations is the privilege of the owners, who alone decide these goals and direct their managers to achieve them. 
It is imperative to distinguish between the term leadership, which is a function, and manager, which refers to a position in a group or organisation. In public or private organisations the formal leaders are called managers or executives. They execute the leadership function. Leadership is part of the managerial process in which the manager guides, supports and motivates the subordinates so that they can fulfil their duties according to the plan of the manager based on the goals of the organisation. In all public and private organisations some individuals are given the authority and responsibility for four basic managerial activities: planning and decision-making, organising, leading and controlling (Griffin 1999). It is worthwhile noting that when Fayol (1916 [1959]) described the managerial functions, he began with planning. A goal is needed in order to plan. In Fayol's view the owners (board of directors) set the goal and the task for the manager is to plan how to achieve the goal. For the manager the goal is an imperative, an order. As Maghroori and Rolland (1997, p. 80) have stated: 'They [managers] do not exist for their own sake. They are to serve the organisation's goal and mission and they remain at all times subservient to it'. A central issue is whether or to what degree the organisation achieves its goal. Consequently, goal-attainment becomes the core issue for the owners, the managers and the other employees, as well as for researchers of organisations.

\subsection{Definition of leadership}

Sayer (1992, p. 91) has posed the following: 'What does the existence of this object (in its present form) presuppose? Can it exist on its own as such? A key question could be: What cannot be removed without making the object cease to exist in its present form?' If the object is leadership, we may ask: What properties must exist for leadership to exist and to be what it is? What makes leadership possible? The argument of 'organisational effectiveness studies' is that the leader, subordinates and tasks are the properties that must exist for managerial leadership to exist and to be what it is. It is crucial to understand that the objects of social science are relational. They are what they are by virtue of the relations they enter with other objects (Danermark et al., 2002). This is the core of managerial leadership as it is related to individuals (leaders and subordinates), tasks and organisations (Yukl 2013). To put it differently, leadership exists when leaders interact with subordinates for the sake of the completion of tasks. These three elements are interdependent: one can't be had without the others. In formal organisations the company or the public agency employ both managers and subordinates, which carries legal and contractual implications. A formal leader (manager) is a person who is responsible both for the subordinates and for the results. Leadership is a process while management is a position (Hughes at al. 1999). Virtually all empirical studies of leadership are based on data from or about managers and their attitudes, work, behaviour, motivation and so on. To designate individuals in senior positions in formal organisations as 'leaders' instead of 'managers' does not make sense in 'organisational effectiveness studies'.

\subsection{Focus on explanation: behaviour and organisational outcomes}

'Organisational effectiveness theories' deal with ontological questions such as what organisations actually are, and also how leaders or managers behave. They are oriented towards causal explanations of relationships.

When the quest for leadership personality was abandoned around 1950, researchers began to focus on the behaviour of leaders, and the consequences of differences in leaders' behavioural patterns. This kind of leadership research - the instrumental 
theories - characterises endeavours of leadership in 'organisational effectiveness studies'. The seminal works of Likert (1961) and the Ohio State researchers (Halpin and Winer 1957; Fleishman and Harris 1962) laid the foundation for this tradition that is characterised by strict definitions of various kinds of behaviour such as leadership style, and subsequently leadership decision-making style, leaders' motivational profiles and conflict-behaviour style, to mention a few. The purpose was originally to describe behaviour. Explaining how leaders' behaviour influences organisational outcomes is, however, the ultimate purpose. Effectiveness is the explanandum. The quest for knowledge on how leadership impacts organisational effectiveness continued with the works of Fiedler (1967) on leadership style and McClelland and Boyatzis (1982) on managers' motivational profiles. The magnitude of leadership effectiveness studies is increasing. They are frequently found in transformational leadership research (for example, Peterson et al. 2009) and recently in the 'expert leader' stance (for example, Goodall and Pogrebna 2015).

\subsection{Method and empirical data in 'organisational effectiveness theories'}

Leadership research deals with many different study objects, such as: (1) leaders' personality, (2) leadership behaviour, (3) leaders' attitudes and values, (4) leadership skills, (5) leaders' activities, (6) leadership roles, (7) managerial work, (8) managerial functions, (9) processes of leadership, (10) leaders' perception and construction of their reality, (11) leadership situations/contexts and (12) leadership effectiveness.

The nature of the object under study is the 'fixed point' from which to start regarding the choice of methods. It is the nature of the object that determines the possibilities we have for gaining knowledge about it (Danermark et al. 2002). Consequently, different methods are applied.

The empirical foundation of 'organisational effectiveness studies' is characterised by large amounts of data from managers, subordinates and organisational variables. The landmark research project from Michigan State University included interviews with managers, subordinates, managers' colleagues and their superiors as well as observation of managers' behaviour in order to describe leadership behaviour (Likert 1961). It is worthwhile noting that more than 350 organisations were studied, with data from more than 20,000 managers on all levels and responses from more than 200,000 subordinates (Likert 1979). The study by Smith et al. (2011) contains data from 7,701 managers from 56 nations. According to the Center for Creative Leadership (2012), the Globe Study collected data from 17,300 managers from 951 organisations in 58 countries.

A large number of these theories became the foundation for leadership training programmes. Fiedler's book (1967) built the basis for a training programme published by Fiedler et al. (1976). The back cover of Blake and Mouton's (1985) book states: 'A new look at the classic that has boosted productivity and profits for thousands of corporations worldwide'. Thus, millions of managers have acknowledged these theories and several others in this group.

\subsection{Status of the field}

The instrumental theories have faced a huge problem regarding the explanation of organisational effectiveness. For a long time it was claimed that there was one best way to lead (that is, universal theories), advocated by Likert $(1961 ; 1979)$ and especially by Blake and Mouton (1964). They were challenged by Fiedler (1967) and 
later by others who claimed that organisational effectiveness was enhanced when the leader's behaviour matched the situation (that is, contingency theories). After a long period of dominance by the contingency argument the universal stance has once again taken the lead. McClelland (1990) has claimed that power-motivated managers were more effective. Bass (1985) and others have argued that transformational leadership is (seen by their subordinates as being) superior to transactional leadership, while Ekvall and Arvonen (1991) have claimed that change-oriented leaders are (seen by their subordinates as being) more proficient.

The fact is that we do not know whether the universal or the contingency argument is to be trusted. We still do not know for sure whether and to what degree managers affect the outcome of organisations. We do not know which leadership factors enhance organisational effectiveness. What we do know is this: leadership is not unimportant. Leadership appears, however, to have far less impact on organisational effectiveness than is commonly believed.

\subsection{Summary of 'organisational effectiveness theories'}

'Organisational effectiveness theories' are based on rationalistic organisation theory which assumes that organisations are instruments for the owners so that the owners can achieve their goals. The owners appoint formal leaders (that is, managers) with the main task of contributing to goal-attainment. Goal-attainment is the central issue and the basic definition of effectiveness. In this tradition, managerial leadership is defined by the properties of leader, subordinates and tasks. The major concern of 'organisational effectiveness theories' is the relationship between leaders' behaviours and actions and organisational effectiveness. The research aims at explaining this relationship. The methods are characterised by strict definitions and quantitative measurements and the use of statistical analyses. These theories are known to and acknowledged by managers.

\section{PROCESS DESCRIPTION LEADERSHIP}

\subsection{Theoretical assumptions on organisations}

The conception of organisation in the scholarship on 'process description theories' which may also be named 'leadership process theories' is influenced by the open system theory. System theory was a reaction to and is an argument against rationalistic theory. Common for open system theories is that organisations are defined as 'congeries of interdependent flows and activities linking shifting coalitions of participants embedded in wider material-resources and institutional environments' (Scott 2003, p. 29). In contrast to the rationalistic theory, system theory does not see the goals as controlling the organisation's activities but conceives the goals as a dependent variable, a product of the activities that take place in the organisation. Or to put it differently, according to rationalistic theory, the goal comes first and then the organisation is established. In system theory, it is the other way round.

This perspective is based on the seminal work of Katz and Kahn (1978). They rejected the idea of studying organisations on the basis of goals. It is imperative to note that Katz and Kahn (ibid.) did not address the issue of ownership. Organisations are dependent on other organisations and groups in order to acquire input and to find outlets for their products and services. Katz and Kahn (ibid.) call other organisations 'constituent groups' or 'constituencies'. 
System theory does not regard the organisation primarily as an instrument for the realisation of the owners' goals. Rather, the organisation is perceived as a structure that responds to and adjusts itself to a multitude of demands from various stakeholders and tries to maintain balance by reconciling these demands. Katz and Kahn (ibid.) have regarded organisational goals as abstractions or generalisations of future activities and behaviour in organisations on a general level.

As systems theory does not regard the organisation primarily as an instrument for the realisation of the owners' goals, the theoretical consequences for leadership theory become far-reaching. The focus of the researchers is thus not on goal-attainment but on organisational activities, including activities of the formal leaders. This is why proponents of the 'process description theories' tradition are less concerned about the impact that leaders might have on organisational outcomes.

\subsection{The definition of leadership}

Scholars of the 'process description theories' stance tend to conflate managerial leadership with leadership of political, humanitarian or religious movements. Managers have subordinates (that is, employees). Political and religious leaders have followers (that is, supporters, members, participants) who are not employed. The definition of leadership proposed by Marturano et al. (2013) permits a leadership concept that does not include tasks. Thus political leadership is subsumed. The conflation of managerial leadership with political leadership creates problems especially with the argument that scholarship on political leadership is relevant and useful for managerial leadership.

Arguably, the properties of leader, subordinates and tasks must exist for managerial leadership to exist and to be what leadership is. What happened to the task in political leadership theory? Burns (1978) does not deal with the challenge of getting followers to perform tasks in order to achieve organisational goals. His book contains 466 pages of running text and the index has 992 words (excluding authors' names). If 'task' is a part or a central part of leadership we would expect to find 'task' mentioned in the running text and amongst the almost 1,000 words in the index. This is not the case. According to Burns's theory, there are no tasks for the followers to solve. Consequently, in the 'process description theories' a leader and followers are the two properties that must exist for leadership to exist, and this is how leadership is defined. Wilson (2013) has also defined leadership with the properties of leader and follower, though without reference to tasks, goals or owners. Leadership studies are dominated by leader-centric conceptions of leadership (ibid.).

\subsection{Focus on description, understanding and process: leader, managerial work and perception of leadership}

'Process description theories' often address epistemological questions and seek to study objects or phenomena which suit the researchers' epistemological answers. 'Process leadership is basically oriented towards understanding from the internal perspective of the leaders themselves. It is the matter of discovering or describing relationships or connections between objects or phenomena.

The theories on leadership as functions, as a process and as skills are descriptive. The experience-based perspective uses the behaviour and activities of knowledgeable and experienced managers as the primary data for theorising about leadership. This perspective draws attention to how management practices are performed in everyday 
work. Mintzberg (1973) has isolated ten leadership roles. Tengblad (2012) is a continuation of Mintzberg's work. As a prominent scholar of the managerial-work tradition, Stewart (1989) has noted that studies of managerial work have failed to look specifically at the relationship between what managers do and what they achieve. 'Process description theories' do not address this causal relationship.

Symbolic theories may also be seen as part of this stance. They are characterised by a focus on what the leader or leadership symbolises or how leadership is perceived. Pfeffer and Salancik (1978) have claimed that one of the leader's functions is to serve as a symbol or personalise the organisation. Other researchers regard leaders as mediators or creators of meaning or meaning structures amongst the subordinates (Smircich and Morgan 1982). They have argued that leadership is about defining the reality of others.

Alvesson and Sveningsson (2003) have studied the meaning managers ascribed to leadership or constructed their leadership, while Holmberg and Tyrstrup (2010) have explored the ways in which managers perceived and described the characteristics of their everyday leadership. Similarly, Kempster (2006) has examined how managers believed that they had learnt how to lead. These are descriptions.

If, however, the purpose is to develop social-science explanations, it is not enough just to collect and repeat the interpretations and explanations that people themselves have of various social phenomena. If the interpretations and explanations of others were the real explanation, there would be no need for social science (Danermark et al. 2002).

Some researchers see or perceive managers as if they were artists and priests or were pedagogues, architects, commanders and saints (Hatch et al. 2006; Amernic et al. 2007). Other writers attribute beauty, wisdom and ethics to leaders (for example, Ladkin 2010). As there are researchers who perceive managers as if they were, for instance, artists, and researchers who attribute beauty etc. to leaders, then leadership becomes something that exists in the heads of the researchers and not the perceptions of leaders.

Stemming from business ethics, the topics of ethics in leadership and ethical behaviour of leaders are evidently topics that attract more and more attention. Bass (1990) has few references to ethics while in Bass (2008) the number has been increased. Yukl (2013) has one chapter on ethical leadership. Crane and Matten (2010) contains a few pages on the specific issue of business ethics and leadership; they wrote: 'Ultimately, given the controversy and debate that continues to rage in the leadership literature, there is unlikely to be any real consensus emerging in relation to ethical leadership' (ibid., p. 224). They added (ibid.) that leadership is an important area of business ethics management, and without top managers' support most of the tools and techniques would not be likely to contribute much to improving business ethics.

More than twenty years ago Ciulla (1995) argued that a greater understanding of ethics in leadership would improve leadership studies. Debates over the definition of leadership are really debates over what researchers think constitutes good leadership. The ultimate question is not 'What is leadership?' but 'What is good leadership?' The word good refers to both ethics and competence. Research into leadership ethics would explore the ethical issues of current leadership research, serve as a critical study of the field, analyse and expand normative theories of leadership, and develop new theories, research questions and ways of thinking about leadership (ibid.).

The terms good or bad in reference to leadership have no meaning theoretically as these terms do not specify good for whom or what. The 'organisational effectiveness theories' argue that leadership is a about organisational goal-attainment while in the 
descriptive stance the terms may imply good or bad for the managers themselves, for employees, customers, for society in general. The terms good or bad reduce leadership scholarship to a matter of general opinion while the ambition of the leadership researcher was obviously to elevate leadership to a scientific endeavour.

Although different, critical management studies (CMS) may be seen as part of the "process description theories' group. One of the influences of CMS comes from the management-practice tradition. However, critical management studies are apparently not part of leadership scholarship as we find no references to CMS either in Bass $(1990 ; 2008)$ or in Yukl (2013). CMS attacks management practice as well as management. Fournier and Grey (2000, p. 7) have described the conditions and prospects of CMS, which they have claimed 'is unified by an anti-performance stance'. They have stated (ibid., p. 17) that '[t]he most obvious boundary would seem to be between work on management which has a performative intent or premise and that which does not'. Some of the goals of CMS are therefore to challenge the oppressive character of management and organisation (Alcadipani and Hassard 2010). The non-performative stance is understood as though CMS were advocating anti-performativity altogether. All theories that address the relationship between leadership and organisational performance and effectiveness are thus attacked. In fact, both management theory and economic theory are rejected.

\subsection{Method and empirical data in 'process description theories'}

As a consequence of the differences in concepts and research objects, studies of 'organisational effectiveness theories' and 'process description theories' differ fundamentally regarding the amount of data collected. Mintzberg (1973) is a frequency study of five North American managers regarding the distribution of time spent on work activities. The ethnographic case study by Smircich and Morgan (1982) is based on data collected during six weeks in a company, observing, interviewing and conversing with ten members of the top management group. Kotter's (1986) study consists of interviews with fifteen managers in the United States. The study of Alvesson and Sveningsson (2003) is based on 40 interviews with Swedish managers on different levels and some scientists, as well as observations of management team meetings. Kempster (2006) has based his conclusions on in-depth interviews with six directors in the same company in the United Kingdom. Holmberg and Tyrstrup (2010) have interviewed 62 Swedish managers. What does it take for a sample of managers to be representative in the United States, for example, with at least 14 million individuals in managerial positions?

\subsection{Status of the field}

The roots of 'process description theories' go back to the classics like Fayol (1916 [1959]), Gulick (1937), Barnard (1938) and the work of Dalton (1959). The managerial work tradition appears to have regained its momentum (Tengblad 2012). The growing focus on the meaning managers ascribe to their leadership, and on the way in which managers describe the characteristics of their leadership, is apparent.

\subsection{Summary of 'process description theories'}

When 'process description theories' pertain to political leadership, leader and followers are the two properties that define leadership. When it pertains to organisations, 
it is based on system theory in which ownership, owners and goals are of marginal importance. The tradition of describing what managers do (that is, managerial work) still flourishes. 'Process description theories' tend to conflate managerial leadership with political leadership. This stance is concerned with the relationship between the leader (managers) and his or her followers (subordinates) and how managers perceive their leadership. The theories provide various understandings of leadership. Some argue that leadership is about the way in which managers define the reality of the subordinates. Even though the methods used are based on the nature of the study objects, the 'process description theories' contain small amounts of data and very few respondents compared with 'organisational effectiveness theories'. CMS argues for researchers' knowledge of management while 'organisational effectiveness theories' are concerned with managers' knowledge of management.

It is hard to find managers who have any knowledge of 'process description theories'. Indeed, these theories are not acknowledged by managers. The descriptions and metaphors as well as the message of CMS are exchanged among and limited to researchers. Table 1 (overleaf) contains the main differences between 'organisational effectiveness studies' and 'process description theories'.

\section{TRANSFORMATIONAL LEADERSHIP: A BINARY THEORY}

Transformational leadership is a new paradigm of leadership that has captured widespread attention and has been heavily promoted over the last few decades (Bass and Riggio 2006; Wilson 2015). The transformational leadership theory is briefly presented in order to illustrate that this theory contains many of the contradictions that have been described above. The theory contains elements from both the 'leadership effectiveness' and the 'descriptive leadership' perspectives. It is a composite theory than can readily be bisected.

Burns (1978) identifies two types of leadership (transformative and transactional) on the basis of a qualitative analysis of the biographies of political leaders. He (ibid., p. 20) views the transformational leader as one who "engages with others in such a way that the leader and the follower raise one another to a higher level of motivation and morality'. Burns's theory is thus a theory of political leadership defined by the properties of leader and followers but not tasks. It is imperative to recognise that Burns's (ibid.) focus was on leadership at the level of societies and movements. Regarding transformational and charismatic leadership, Avolio and Yammarino (2002, p. xvii) have noted that 'there are nearly as many definitions of these notions as there are researchers in the field'.

This scope for the evaluation of the leader's success in the transformation of followers in respect of 'higher levels of motivation and morality' in societies can be contrasted with the typical situations in private enterprises. Firms are goal-oriented entities. Thus, the applicability of ideological leadership that can emerge and operate at a societal level might be limited in private and public organisations (Pawar 2003). According to Khanin (2007) there is growing evidence that transformational leadership may not address the specific needs of leadership in public agencies and private enterprises.

The core of managerial leadership is that managers are hired to contribute to the attainment of organisational goals, which can only be achieved by having subordinates performing tasks that lead to productivity and effectiveness. Political and religious leaders have followers (that is, supporters, members, participants). The goal is the goal of 
Table 1 Main differences between 'organisational effectiveness theories' and 'process description theories'

\begin{tabular}{|c|c|c|}
\hline Organisational effectiveness theories & & Process description theories \\
\hline $\begin{array}{l}\text { Organisations are contrived by } \\
\text { owners. } \\
\text { The owners' goals are the } \\
\text { organisations' goals. } \\
\text { Goal-attainment is the purpose of the } \\
\text { organisation. }\end{array}$ & $\begin{array}{l}\text { Organisational } \\
\text { concept }\end{array}$ & $\begin{array}{l}\text { Social, political or religious } \\
\text { movements and organisations. } \\
\text { Stakeholders and leaders. } \\
\text { The goals are the goals of the } \\
\text { leader or common goals. }\end{array}$ \\
\hline $\begin{array}{l}\text { Leaders, subordinates and tasks are } \\
\text { the properties that must exist for } \\
\text { managerial leadership to exist. } \\
\text { Leaders and subordinates are employed } \\
\text { by the organisation. } \\
\text { The manager is the owners' extended } \\
\text { arm. }\end{array}$ & $\begin{array}{l}\text { Leadership } \\
\text { concept }\end{array}$ & $\begin{array}{l}\text { Leader and followers are the } \\
\text { properties that must exist for } \\
\text { political leadership to exist (no } \\
\text { tasks). } \\
\text { Leaders and followers are not } \\
\text { employed. } \\
\text { The manager is performing a } \\
\text { balancing act. }\end{array}$ \\
\hline $\begin{array}{l}\text { The purpose is to explain causal } \\
\text { relationships between leadership } \\
\text { behaviour and organisational } \\
\text { effectiveness. }\end{array}$ & Research focus & $\begin{array}{l}\text { The purpose is to describe and } \\
\text { understand relationships and } \\
\text { perceptions of leadership. }\end{array}$ \\
\hline $\begin{array}{l}\text { Leadership research addresses many } \\
\text { different study objects, thus there is } \\
\text { no best method. } \\
\text { The methods are characterised by } \\
\text { strict definitions and quantitative } \\
\text { measurements and the use of } \\
\text { statistical analyses. }\end{array}$ & Methods & $\begin{array}{l}\text { Few study objects are researched. } \\
\text { A preference for methods like } \\
\text { participant observation } \\
\text { (ethnographic method), case } \\
\text { studies, metaphors and } \\
\text { interviews. }\end{array}$ \\
\hline $\begin{array}{l}\text { Likert (1979): data from more than } \\
20,000 \text { managers on all levels and } \\
\text { responses from more than } 200,000 \\
\text { subordinates in } 350 \text { organisations. } \\
\text { Smith et al. (2011): data from } 7,701 \\
\text { managers from } 56 \text { nations. } \\
\text { Center for Creative Leadership } \\
\text { (2012): data from } 17,300 \text { managers } \\
\text { in } 951 \text { organisations in } 58 \\
\text { countries. }\end{array}$ & $\begin{array}{l}\text { Empirical data } \\
\text { (examples) }\end{array}$ & $\begin{array}{l}\text { Mintzberg (1973): data from } \\
5 \text { managers. } \\
\text { Smircich and Morgan (1982): data } \\
\text { collected during } 6 \text { weeks by } \\
\text { observing and interviewing } 10 \\
\text { top managers. } \\
\text { Kotter (1986): interviews with } 15 \\
\text { managers. } \\
\text { Alvesson and Sveningsson (2003): } \\
40 \text { interviews with managers } \\
\text { plus observations of } \\
\text { management team meetings. }\end{array}$ \\
\hline
\end{tabular}

the leader or a common goal. The followers are not given specific tasks to do. The argument that scholarship on political leadership is relevant and useful for managerial leadership has turned out to be fraught with difficulties.

Bass (1985) claimed that transformational leadership is superior to other kinds of leadership. Others also assert that the transformational leadership theory is a universal theory, implying that transformational leaders are more effective than transactional ones, no matter what the organisational specifics might be or what country it is practised in or what kind of organisation adopts it (Smith and Peterson 1990; Hughes et al. 1999). Theories on leadership effectiveness are either universal (that is, asserting that 
there is one best way to lead) or contingent (that is, effectiveness depends on the situation or context). The corollary is that a theory cannot be both universal and contingent. Several scholars have claimed that transformational leadership is always more effective than transactional leadership. With these propositions in mind, can we say that the transformational theory is really a universal one? Bass (1985) stated that environmental and organisational characteristics are likely to have an impact on the degree to which transformational leadership results in organisational effectiveness. Yet if that is the case then it is not a universal theory.

The universal theories were criticised by Fiedler's (1967) seminal work by introducing situational factors into the explanations of effectiveness. A large number of researchers on transformational leadership report support for contingency factors: Howell and Avolio (1993) for innovation; Lowe et al. (1996) for stable versus turbulent environments, industrial sector and organisation size; Waldman and Yammarino (1999) for environmental volatility; Shamir and Howell (1999) for organisation culture; Peterson et al. (2009) for start-up versus established firms; Walter and Bruch (2010) for organisational structure; Menges et al. (2011) for affective climate and trust climate; and Rowold (2011) for facets of team members' heterogeneity. Additionally, Mannheim and Halamish (2008) did not find support for the predicted universality of the theory. Antonakis et al. (2003) and Bass and Riggio (2006) have emphasised that environmental and organisational factors will most likely influence the degree to which transformational leadership impacts organisational effectiveness. No explicit situational (contextual) variable is present in the theoretical framework. However, in order to 'save' the theory, situational arguments inevitably surface from time to time.

In most transformational leadership studies based on the Multifactor Leadership Questionnaire (MLQ) (Bass and Riggio 2006) we find that effectiveness and performance are measured subjectively. The vast majority of studies on effectiveness are based on responses from the subordinates regarding to what degree they feel, think or assume that their respective manager is successful. Additionally, if effectiveness is a dependent variable and defined (1) as a ratio and (2) as the degree of goalattainment, and where (3) the goal is profitability and (4) the measurement of profitability is objective, then there is virtually no evidence that transformational leadership explains organisational effectiveness. Dumdum et al. (2002) found that many more studies utilised subjective measures of effectiveness than objective measurements of the same variable. They suggested that it would be advantageous to build a broader database with objective measures. Furthermore, Dumdum et al. (ibid.) concluded that any researcher going through this coding exercise cannot help but be struck by the fact that there are still too few studies using objective measures of effectiveness.

Burns's consistent use of the term 'follower' instead of 'subordinate' when investigating private companies is especially unfortunate because recent scholars continue to do the same. According to Webster's Dictionary (1989, p. 551) 'a follower is "a person who follows others in regard to his ideas and belief; disciple or adherent." The term is a synonym of (1) adherent, meaning one who gives full loyalty and support to another. Follower may apply to people who attach themselves either to the person or beliefs of another; or (2) of adherent, which suggests a close and persistent attachment; or (3) disciple, implying a devoted allegiance to the teachings of one chosen as a master; or even (4) partisan, which suggests a zealous often prejudiced attachment'. Nothing is gained by calling individuals in subordinate positions 'followers'. Political and religious leaders have followers. Managers have subordinates, not followers. This kind of muddling is illustrated in Seltzer and Bass (1990, p. 694), who - in the very same sentence - use these two terms indiscriminately: 'Transformational leaders may inspire 
their followers, may deal individually with subordinates to meet their developmental needs ...'.

Contemporary researchers use the term follower even though their investigations concern private companies or public agencies. It is indicative of this implicit bias that Simola et al. (2010) use the term follower 50 times and never refer to subordinate at all. Nahum-Shani and Somech (2011) employ the word follower 71 times and subordinate only three times. Similarly, in Holstad et al. (2014) the term follower appears 46 times and the term employee only once ('A sample of 199 employees participated'). We may ask whether we want managers to perceive and interact with their subordinates the way that religious and political leaders do. Additionally, van Knippenberg and Sitkin (2013, p. 49) concluded 'that the field will be better off when it abandons the charismatic-transformational leadership concept'.

The transformational leadership theory is presented in order to illustrate that aspects of both 'organisational effectiveness theories' and 'process description theories' are found in transformational leadership theory. However, a theory on political leadership cannot also be a theory of managerial leadership because these study objects are not the same. The individuals that the leader interacts with cannot be followers and subordinates at the same time. The consequences or effects of leaders' actions cannot be comparable in political or social movements to the outcomes in private companies or public agencies. A theory which claims that transformational leadership is the best way to lead with regard to organisational effectiveness cannot at the same time rest on the universal argument and the contingency argument. Khanin (2007) has, in fact, proposed that the differences between Burn's (1978) and Bass's (1985) conceptions of leadership are so substantial that they should not be regarded as a single theory. The transformational leadership theory has one basis in 'organisational effectiveness studies' and another in 'process description theories', and can thus easily fall asunder. According to van Knippenberg and Sitkin (2013) it already has.

\section{A PROBLEMATIC END VARIABLE}

The most basic difference between effectiveness and description theories concerns explanation versus understanding. It can be rephrased to be a matter of whether organisational goal-attainment is the ultimate problem for leadership research to solve or not. Organisational effectiveness defined as organisational goal-attainment is thus a watershed between these two kinds of leadership theories. For this reason, a closer look at effectiveness as the end variable is called for. Yukl $(2013$, p. 18) writes that ' $[t]$ he focus of much of the research has been on the determinants of leadership effectiveness'. If organisational effectiveness is what leadership research is supposed to explain, then the definition and measurement of the term becomes imperative. In business administration, profitability can be seen as the major criterion of effectiveness for private enterprises. Profitability (that is, return on investment, cash flow, and marketshare change) is the most conventional measure of current business performance (Hambrick 1983). The ultimate goal of a company is profitability (that is, degree of return on assets) (Shetty 1979; Nash 1983; Walton and Dawson 2001).

Effectiveness is an objective variable. It is a measurable ratio. It is, indeed, difficult in practice to get access to and to collect effectiveness data linked to managers who are preferably on the same level in the same organisation or in similar organisations and operating under as equal conditions as possible. Consequently, we find very few empirical studies of leadership and organisational effectiveness which fulfil these 
theoretical requirements. Researchers have, therefore, taken other roads: (1) substitutes for effectiveness or intermediate (intervening) variables like subordinates' motivation, commitment, creativity and work climate are used, or (2) effectiveness is abandoned and performance variables like profit, sales, stock prices as well as efficiency and productivity are employed (for example, Ployhart et al. 2001). These are independent variables that may enhance organisational effectiveness, or (3) effectiveness and performance are measured subjectively (managers were seen by their subordinates to be efficient) (for example, Bass and Riggio 2006).

All these alternatives jettison leadership research or at least jeopardise the scholarship on 'organisational effectiveness theories'. A large theoretical leap is taken when the standpoint that organisational effectiveness and performance is of marginal importance is turned into the 'anti-performance' stance held by CMS. As if this were not enough, CMS goes all the way, claiming that management is bad.

\section{CONCLUSION}

'Organisational effectiveness theories' represent an outward force or movement from the behaviour and actions of the leader with a focus on the tasks the subordinates need to perform to the achievement of goals. This kind of leadership theory draws attention to the leadership situation and the organisational context. The formal leaders' main task is to contribute to the attainment of the goals as decided by the owners. The end variable of 'organisational effectiveness theories' is organisational goal-attainment. The scholarship of the 'organisational effectiveness theories' is acknowledged by managers.

'Process description theories' represent an inward force or movement from organisational and societal contexts into the leader as a person. The external force or influence comes to the leader through the relationship with the followers. The leader and the follower enter a relationship described as, for instance, one of 'mutual stimulation and elevation'. Leadership is also a matter of how managers construct and describe their leadership. Thus, the end variable of 'process description theories' is what goes on in the minds of the leaders, or, in the management-of-meaning stance, what reality or meanings end up in the heads of the subordinates. These theories are seldom known to managers. The message of what may also be called 'leadership process theories' has not expanded beyond the understanding and scholarship stored among the researchers themselves.

Scholarship on 'organisational effectiveness theories' pertains to leadership in formal organisations where organisations are perceived as vehicles for the achievement of the goals of the owners, whether they are private or public ones. On 'process description theories' the scholarship pertains to leadership in political, religious or social movements and organisations where the goals are those of the leaders or common goals. Theoretical advances in managerial leadership or in political leadership are neither applicable nor beneficial for each other because what leadership is all about and what to lead are fundamentally different. Additionally, the purpose of 'organisational effectiveness theories', which is to find causal explanations, contrasts sharply with the purpose of 'process description theories', which is to describe and understand leadership. The purpose of the latter is in fact to understand a kind of leadership that differs from that of leadership effectiveness. The difference between these two groups of leadership scholarship is at its most profound when managerial leadership's focus on organisational effectiveness is confronted with an anti-performance argument. 
By acknowledging these contrasts, conflicts and contradictions between 'organisational effectiveness theories' and 'process description theories', we can understand the present state of leadership scholarship. A critical result of these divergent emphases is that the theoretical relationships between these two groups of scholarship appear to have ended. Advancements in one area may no longer be beneficial to other areas. It behoves us to consider the consequences of this present bifurcated state. We ought to take seriously the proposition that leadership researchers, and, in the final analysis, managers are all losers if the present state prevails. Can it be mended? If so, how and by whom?

In order to return to the citation that inspired these observations on the current state of leadership scholarship, the labels 'organisational effectiveness studies' and 'process description theories', which so far have been applied to the groups of leadership theories, will now be named 'leadership of today' and 'leadership of yesterday'. Again, there is no temporal or historical dimension to these two groups. Yet which group is which is inconsequential.

Sometimes, in conversation with other leadership researchers, I relate some basic concepts and findings in leadership of yesterday, and I notice from their astonished questions how much that is obvious mainstream scholarship to me is incomprehensible to them. And, to paraphrase Zweig, some instinct tells me that they are right. All bridges between leadership of today and leadership of yesterday have been burned.

\section{ACKNOWLEDGEMENT}

The author is grateful for the valuable comments of Professor Owe L. Johansson, Örebro University School of Business, Örebro University, Sweden.

\section{REFERENCES}

Alcadipani, R. and J. Hassard (2010), 'Actor-network theory, organizations and critique: towards a politics of organizing', Organization, 17(4), 419-435.

Alvesson, M. and S. Sveningsson (2003), 'The great disappearing act: difficulties in doing "leadership"”, The Leadership Quarterly, 14(3), 359-381.

Amernic, J., R. Craig and D. Toursh (2007), 'The transformational leader as pedagogue, physician, architect, commandeer, and saint: five root metaphors in Jack Welch's letters to stockholders of General Electric', Human Relations, 60(12), 1839-1872.

Antonakis, J., B.J. Avolio and N. Sivasubramaniam (2003), 'Context and leadership: an examination of the nine-factor full-range leadership theory using the Multifactor Leadership Questionnaire', The Leadership Quarterly, 14(3), 261-295.

Antonakis, J., A.T. Cianciolo and R.J. Sternberg (2004), The Nature of Leadership, Thousand Oaks, CA: Sage.

Avolio, B.J. and F.J. Yammarino (2002), 'Introduction to, and overview of, transformational and charismatic leadership', in B.J. Avolio and F.J. Yammarino (eds), Transformational and Charismatic Leadership: The Road Ahead, Amsterdam: JAI, Elsevier Science, pp. xvii-xxii.

Barnard, C.I. (1938), The Functions of the Executive, Boston: Harvard University Press.

Bass, B.M. (1985), Leadership and Performance Beyond Expectations, New York: Free Press.

Bass, B.M. (1990), Bass and Stogdill's Handbook of Leadership: Theory, Research and Managerial Applications, New York: Free Press.

Bass, B.M. (2008), The Bass Handbook of Leadership: Theory, Research and Managerial Applications, New York: Free Press. 
Bass, B.M. and R.E. Riggio (2006), Transformational Leadership, Mahwah, NJ: Lawrence Erlbaum.

Blake, R.R. and J.S. Mouton (1964), The Managerial Grid, Houston, TX: Gulf Publishing.

Blake, R.R. and J.S. Mouton (1985), The Managerial Grid III, Houston, TX: Gulf Publishing. Bryman, A. (1996), 'Leadership in organizations', in S.R. Clegg, C. Hardy and W.R. Nord (eds), Handbook of Organizational Studies, London: Sage, pp. 276-292.

Burns, J.M. (1978), Leadership, New York: Harper and Row.

Center for Creative Leadership (2012), Leader Effectiveness and Culture: The Globe Study, available at: www.ccl.org/leadership/pdf/.../GlobeStudy.

Ciulla, J.B. (1995), 'Leadership ethics: mapping the territory', Business Ethics Quarterly, 5(1), $5-28$.

Crane, A. and D. Matten (2010), Business Ethics, Oxford: Oxford University Press.

Dalton, M. (1959), Men who Manage: Fusion of Feeling and Theory in Administration, New York: John Wiley.

Danermark, B., M. Ekström, L. Jakobsen and J.C. Karlsson (2002), Explaining Society: Critical Realism in the Social Sciences, London: Routledge.

Dumdum, U.R., K.B. Lowe and B.J. Avolio (2002), 'A meta-analysis of transformational and transactional leadership correlated of effectiveness and satisfaction', in B.J. Avolio and F.J. Yammarino (eds), Transformational and Charismatic Leadership: The Road Ahead, Amsterdam: JAI, Elsevier Science, pp. 35-66.

Ekvall, G. and J. Arvonen (1991), 'Change-centered leadership: an extension of the two-dimensional model', Scandinavian Journal of Management, 7(1), 17-26.

Fayol, H. (1916 [1959]), General and Industrial Management, London: Pitman.

Fiedler, F.E. (1967), A Theory of Leadership Effectiveness, New York: McGraw-Hill.

Fiedler, F.E., M.M. Chemers and L. Mahar (1976), Improving Leadership Effectiveness: The Leadership Match Concept, New York: John Wiley.

Fleishman, E.A. and E.F. Harris (1962), 'Patterns of leadership behavior related to employee grievances and turnover', Personnel Psychology, 15(1), 43-56.

Fournier, V. and C. Grey (2000), 'At the critical moment: conditions and prospects of critical management studies', Human Relations, 53(1), 7-32.

Goodall, A.H. and G. Pogrebna (2015), 'Expert leaders in a fast moving environment', The Leadership Quarterly, 26(2), 123-142.

Griffin, R.W. (1999), Management, Boston: Houghton Mifflin.

Gulick, L. (1937), 'Notes on the theory of organization', in L. Gulick and L. Urwick (eds), Papers on the Science of Administration, New York: Institute of Public Administration, pp. 2-45.

Halpin, A.W. and B.J. Winer (1957), 'A factoral study of the leader behavior descriptions', in R.M. Stogdill and A.E. Coons (eds), Leader Behavior: Its Description and Measurement, Columbus: Ohio State University, Bureau of Business Research, pp. 39-51.

Hambrick, D.C. (1983), 'Some tests of the effectiveness and functional attributes of Miles and Snow's strategic types', Academy of Management Journal, 26(1), 5-26.

Hatch, M.J., M. Kostera and A.K. Kozminski (2006), 'The three faces of leadership: manager, artist, priest', Organizational Dynamics, 35(1), 49-68.

Holmberg, I. and M. Tyrstrup (2010), 'Well then - what now? An everyday approach to managerial leadership', Leadership, 6(4), 353-372.

Holstad, T.J., S. Korek, T. Rigotti and G. Mohr (2014), 'The relation between transformational leadership and follower emotional strain: the moderating role of professional ambition', Leadership, 10(3), 269-288.

Howell, J.M. and J. Avolio (1993), 'Transformational leadership, transactional leadership, locus of control, and support for innovation: key predictors of consolidated-business-unit performance', Journal of Applied Psychology, 78(6), 891-902.

Hughes, R.L., R.C. Ginnett and G.J. Curphy (1999), Leadership, Boston: McGraw-Hill.

Katz, D. and R.L. Kahn (1978), The Social Psychology of Organizations, New York: John Wiley. 
Kempster, S. (2006), 'Leadership learning through lived experience: a process of apprenticeship?', Journal of Management and Organization, 12(1), 4-22.

Khanin, D. (2007), 'Contrasting Burns and Bass: does the transformational paradigm live up to Burns's philosophy of transforming leadership?', Journal of Leadership Studies, 1(3), 7-25.

Kotter, J.P. (1986), The General Managers, New York: Free Press.

Ladkin, D. (2010), Rethinking Leadership: A New Look at Old Leadership Questions, Cheltenham, UK and Northampton, MA: Edward Elgar.

Letza, S., X. Sun and J. Kirkbride (2004), 'Shareholding versus stakeholding: a critical review of corporate governance', Corporate Governance, 12(3), 242-262.

Likert, R. (1961), New Patterns of Management, New York: McGraw-Hill.

Likert, R. (1979), 'From production- and employee-centeredness to systems 1-4', Journal of Management, 5(2), 147-156.

Lowe, K.B., K.G. Kroek and N. Sivasubramaniam (1996), 'Effectiveness correlates of transformational and transactional leadership: a meta-analytic review of the MLQ literature', The Leadership Quarterly, 7(3), 385-425.

Maghroori, R. and E. Rolland (1997), 'Strategic leadership: the art of balancing organizational mission with policy, procedures, and external environment', Journal of Leadership and Organizational Studies, 4(2), 62-81.

Mannheim, B. and H. Halamish (2008), 'Transformational leadership as related to team outcomes and contextual moderation', Leadership and Organization Development Journal, 29(7), 617-630.

Marturano, A., T. Wren and M. Harvey (2013), 'Editorial: the making of leadership and the humanities', Leadership and the Humanities, 1(1), 1-5.

McClelland, D.C. (1990), Human Motivation, Cambridge, UK: Cambridge University Press.

McClelland, D.C. and R. Boyatzis (1982), 'Leadership motive pattern and long-term success in management', Journal of Applied Psychology, 67(6), 737-743.

Menges, J.I., F. Walter, B. Vogel and H. Bruch (2011), 'Transformational leadership climate: performance linkages, mechanisms, and boundary conditions at the organizational level', The Leadership Quarterly, 22(5), 893-909.

Mintzberg, H. (1973), The Nature of Managerial Work, New York: Prentice-Hall.

Nahum-Shani, I. and A. Somech (2011), 'Leadership. OCB and individual differences: idiocentrism and allocentrism as moderators of the relationship between transformational and transactional leadership and OCB', The Leadership Quarterly, 22(2), 353-366.

Nash, M. (1983), Managing Organizational Performance, San Francisco, CA: Jossey-Bass.

Pawar, B.S. (2003), 'Central conceptual issues in transformational leadership research', Leadership and Organization Development Journal, 24(7), 397-406.

Peterson, S.J., F.O. Walumba, K. Byron and J. Myrowitz (2009), 'CEO positive psychological traits, transformational leadership, and firm performance in high-technology start-up and established firms', Journal of Management, 35(2), 348-368.

Pfeffer, J. and G.R. Salancik (1978), The External Control of Organizations, New York: Harper and Row.

Ployhart, R.E., B.-C. Lim and K.-Y. Chan (2001), 'Exploring relations between typical and maximum performance ratings and the five factor model of personality', Personal Psychology, 54(4), 809-843.

Richards, T. (2015), Dilemmas of Leadership, London: Routledge.

Rowold, J. (2011), 'Relationship between leadership behaviors and performance: the moderating role of a work team's level of age, gender, and cultural heterogeneity', Leadership and Organization Development Journal, 32(6), 628-647.

Sayer, A. (1992), Method in Social Science: A Realist Approach, London: Routledge.

Scott, R.W. (2003), Organizations: Rational, Natural, and Open Systems, Upper Saddle River, NJ: Prentice-Hall.

Seltzer, J. and B.M. Bass (1990), 'Transformational leadership: beyond initiation and consideration', Journal of Management, 16(4), 693-703.

Shamir, B. and J.M. Howell (1999), 'Organizational and contextual influences on the emergence and effectiveness of charismatic leadership', The Leadership Quarterly, 10(2), 257-283. 
Shetty, Y.K. (1979), 'New look at corporate goals', California Management Review, 16(2), 71-79.

Simola, S.K., J. Barling and N. Turner (2010), 'Transformational leadership and leader moral orientation: contrasting an ethic of justice and an ethic of care', The Leadership Quarterly, 21(1), 179-188.

Smircich, L. and G. Morgan (1982), 'Leadership: the management of meaning', Journal of Applied Behavioral Science, 18(2), 2-73.

Smith, P.B. and M.F. Peterson (1990), Leadership, Organizations and Culture, Sage: London.

Smith, P.B., M.F. Peterson, S.J. Thomason and The Event Management Research Meaning Group (2011), 'National culture as a moderator of the relationship between managers' use of guidance sources and how well work events are handled', Journal of Cross-Cultural Psychology, 42(6), 1101-1121.

Stewart, R. (1989), 'Studies of managerial jobs and behaviour: the ways forward', Journal of Management Studies, 26(1), 1-10.

Tengblad, S. (2012), The Work of Managers: Towards a Practice Theory of Management, Oxford: Oxford University Press.

Van Knippenberg, D. and S.B. Sitkin (2013), 'A critical assessment of charismatic-transformational leadership research: back to the drawing board?', The Academy of Management Annals, $7(1), 1-60$.

Waldman, D.A. and F.J. Yammarino (1999), 'CEO charismatic leadership: levels-of-management and levels-of-analysis effects', Academy of Management Review, 24(2), 266-285.

Walter, F. and H. Bruch (2010), 'Structural impacts on the occurrence and effectiveness of transformational leadership: an empirical study at the organizational level of analysis', The Leadership Quarterly, 21(5), 765-782.

Walton, E. and S. Dawson (2001), 'Managers' perception of criteria of organizational effectiveness', Journal of Management Studies, 38(2), 173-199.

Webster's Encyclopedic Unabridged Dictionary of the English Language (1989), New York: Gramer Books.

Wilson, S. (2013), 'Situated knowledge: a Foucauldian reading of ancient and modern classics of leadership thought', Leadership, 9(1), 43-61.

Wilson, S. (2015), 'The dark side of transformational leadership: a critical perspective - book review', Organization, 22(1), 150-153.

Yukl, G.A. (2013), Leadership in Organizations, Harlow: Pearson.

Zweig, S. (1943 [1964]), The World of Yesterday, Lincoln, NE: University of Nebraska Press. 